\title{
Genotyping-by-Sequencing for Analysis of the Genetic Variation of Podosphaera xanthii, Incitant of Cucurbit Powdery Mildew
}

\author{
Y. Xiang, ${ }^{1}$ A. N. Miller, ${ }^{2}$ M. McGrath, ${ }^{3}$ and M. Babadoost ${ }^{1, \dagger}$ \\ ${ }^{1}$ Department of Crop Sciences, University of Illinois, Urbana, IL 61801 \\ ${ }^{2}$ Illinois Natural History Survey, University of Illinois, Champaign, IL 61820 \\ ${ }^{3}$ Cornell University, Riverhead, NY 11901
}

\begin{abstract}
This research was conducted to identify species causing powdery mildew on cucurbits and to determine genetic variations among isolates of the pathogen. We collected 109 isolates from six cucurbit species hosts (Cucumis melo, Cucumis sativus, Cucurbita maxima, Cucurbita moschata, Cucurbita pepo, and Lagenaria siceraria) in California, Illinois, Indiana, Michigan, New York, Texas, Washington, and Wisconsin in the United States and in Italy. By sequencing the internal

was applied to these 109 isolates to investigate their genetic diversity, which showed a trend of isolates clustering from New York and Italy. In addition, the virulence of 36 isolates was compared and a significant difference $(P<0.0001)$ was found among them. Furthermore, results of the virulence tests of 28 isolates from Illinois showed significant effects of collection years, hosts, and locations on the virulence of the isolates.
\end{abstract} transcribed spacer region of the nuclear rDNA of these 109 isolates, Podosphaera xanthii was found as the only species causing powdery mildew on cucurbits in the United States. Genotyping-by-sequencing
Keywords: cucurbits, genetic variation, Podosphaera xanthii, powdery mildew, virulence variation
Cucurbits grown in the United States are cantaloupe (Cucumis melo L.), cucumber (Cucumis sativus L.), gourd [Lagenaria siceraria (Molina) Standley], jack-o'-lantern pumpkin (Cucurbita pepo L.), processing pumpkin (Cucurbita moschata Duchesne), squash (Cucurbita maxima Duchesne ex Lam), watermelon [Citrullus lanatus ((Thunberg) Matsumura \& Nakai)], yellow squash (Cucurbita pepo L.), and zucchini (Cucurbita pepo L.). Approximately 12,000 ha of cucurbits are produced annually in Illinois, which includes approximately 4,000 ha of jack-o'-lantern pumpkins, 5,600 ha of processing pumpkins (representing about $90 \%$ of commercial processing pumpkins produced in the United States), and 2,400 ha of other cucurbit crops (Islam and Babadoost et al. 2005; Jossey and Babadoost 2008; Ravanlou and Babadoost 2015).

Powdery mildew on cucurbits is caused by two species: Podosphaera xanthii (Castagne) U. Braun \& N. Shishkoff [synonym: Sphaerotheca fuliginea (Schlecht ex Fr.) Poll; formerly Sphaerotheca fusca (Fr.) Blumer, Beitr. Krypt.-Fl. Schweiz] and Golovinomyces cichoracearum var. cichoracearum (D.C.) V.P. Heluta [synonym: Erysiphe cichoracearum (D.C. ex Merat)]. P. xanthii has been reported worldwide, whereas $G$. cichoracearum has been mainly reported from France, Spain, and the Czech Republic (Lebeda et al. 2011). The most common symptom or sign of powdery mildew on cucurbits is the white colonies on the leaf surfaces, petioles, and stems (McGrath 2017; Pérez-García et al. 2009). The white colonies are composed of mycelia and conidia (Glawe 2008; McGrath 2017). Under favorable conditions, the colonies expand and merge together and cause chlorosis and early senescence of leaves. Severe early senescence of leaves exposes fruit to sunscald and decreases the number and size of fruits (McGrath 2017). Early senescence of leaves can

${ }^{\dagger}$ Corresponding author: M. Babadoost; babadoos@illinois.edu

Funding: This research was supported in part by a U.S. Department of Agriculture-Illinois Department of Agriculture Specialty Crops Grant (project SC-17-19).

The author(s) declare no conflict of interest.

Accepted for publication 3 September 2019.

(c) 2020 The American Phytopathological Society also result in decreased market value attributable to poor storability and flavor, low soluble solids, poor rind color, and shriveled and discolored handles. In cantaloupe plants, advanced pathogen infection may result in decreased sugar content in fruit, which ultimately leads to decreased fruit quality and marketability. In other cucurbits such as cucumber, yellow squash, and zucchini, infection may directly cause reduced yield and quality (McGrath 2017).

Powdery mildew occurs wherever cucurbits are grown in the world. Powdery mildew on cucurbits develops around the middle of July in Illinois and is commonly observed in August and September in commercial fields. The primary sources of initial inoculum have not been determined, but it is possible that airborne conidia travel from the Southern states where cucurbits are grown during winter. Inoculum may also come from infected cucurbits grown in local greenhouses. As obligate parasites, powdery mildew fungi can only survive with host plants and as overwintering chasmothecia, which are rarely found in the field in the United States (McGrath 2017). Chasmothecia have not been reported on cucurbits in Illinois or other Midwestern states.

Powdery mildew pathogens are identified by their morphological features and using molecular techniques. Morphological identification of powdery mildew fungi on cucurbits is based mainly on characteristics of the asexual state, including the shape and size of conidia, presence of fibrosin bodies, and morphology of the germ tubes (Kř́stková et al. 2009; Lebeda 1983). Identification using molecular methods is mainly based on sequences of the nuclear rDNA internal transcribed spacer (ITS) region (Al-Sadi et al. 2012; Chen et al. 2008; Garibaldi et al. 2011; Pérez-García et al. 2009).

Determining genetic variation of pathogens helps in the development of effective strategies for management of plant diseases, such as fungicide resistance management and breeding disease-resistant host cultivars (Burdon 1993; McGrath 2001; McGrath et al. 2019; Miazzi et al. 2011; Pirondi et al. 2015). To our knowledge, no investigation of the genetic or virulence variance of the fungus causing powdery mildew on cucurbits in Illinois has been carried out. The objectives of this study were to identify species causing powdery mildew on cucurbits and to determine genetic and virulence variation among isolates of the pathogen.

\section{Materials and Methods}

Collection of isolates. A total of 109 P. xanthii isolates were collected and studied, which included 105 samples from the United 
States (102 isolates from field leaf samples and three isolates from in vitro cultures) and four samples from extracted DNA from leaf samples in Italy (Table 1). Leaf samples with powdery mildew were collected from commercial fields of various cucurbit species in seven U.S. states, including California, Illinois, Indiana, Michigan, Texas, Washington, and Wisconsin, during July to September in 2014, 2015 , and 2016 (Table 1). Three in vitro isolates were provided by Margaret McGrath from Cornell University in 2015, which were originally collected from Cucurbita pepo in New York state. Because of the difficulty with international shipping of living fungal samples, four $P$. xanthii isolates were extracted to DNA samples and shipped to the United States by Dr. Alessandro Pirondi from Italy in 2015, which were originally collected from Cucumis melo, Cucumis sativus, and Cucurbita pepo in Italy (Table 1).

Pathogen isolation from field leaf samples. A total of 102 singlecolony isolates were obtained from field leaf samples using the methods reported by Nicot et al. (2002). Seeds of cucumber cultivar Bush Crop (Rupp Seeds Inc., Wauseon, $\mathrm{OH}$ ), susceptible to powdery mildew, were sown in Sunshine Mix LC1 (Sun Gro Horticulture, Agawam, MA) in $27 \times 54 \times 6-\mathrm{cm}$ flats at a rate of 90 seeds per flat. Plants were grown in a greenhouse at 22.5 to $25^{\circ} \mathrm{C}$ during the day and 16.5 to $18.5^{\circ} \mathrm{C}$ during the night and with a $14-\mathrm{h}$ photoperiod at a light intensity of $436 \mu \mathrm{E} / \mathrm{m}^{2} / \mathrm{s}$. Plants were watered daily. Approximately 1 week after the seeds were sown, those with fully expanded cotyledons were harvested. The cotyledons were rinsed with tap water to remove soil particles, rinsed with a $0.6 \%$ sodium hypochlorite solution to disinfest surfaces of the leaves, and then rinsed twice with sterile distilled water. Two clean cotyledons were placed with abaxial surfaces facing down in each 100-mm-diameter Petri plate containing $20 \mathrm{ml}$ of water agar with antibiotics (WAA) (18 g of agar, $20 \mathrm{mg}$ of pimaricin in 1 liter of distilled water). Plates with cotyledons were left in the laminar hood to air dry before inoculation.

From each leaf sample with powdery mildew, one isolate was prepared on two to three cotyledons in one Petri plate from a single colony on the field leaf sample. Conidia from these colonies were transferred onto separate surface-disinfected cotyledons in WAA plates using sterilized pipette tips. The inoculated cotyledons were placed in a growth chamber at $25^{\circ} \mathrm{C}$ and 12 -h of light/12-h of darkness for 2 weeks before DNA extraction. The cultures were maintained by subculturing every 2 weeks on detached and surfacedisinfested cucumber cotyledons on WAA in Petri plates, prepared using the above-mentioned procedure, and plates were incubated in the same growth chamber.

Morphology of conidia. Thirty-two leaf-sample isolates collected from Illinois in 2014 and 2015 were randomly selected for studying the morphology of conidia. Conidia were examined using a compound light microscope (Optical Analysis Corporation, Nashua, $\mathrm{NH}$ ) and the following morphological characteristics were recorded: (i) widths and lengths of 25 arbitrarily chosen conidia for each isolate and (ii) the presence of fibrosin bodies within these conidia.

Table 1. Host crops and their locations of 109 isolates of cucurbit powdery mildew fungi used for molecular identification of species and genotypingby-sequencing

\begin{tabular}{|c|c|c|c|c|c|c|c|c|c|c|}
\hline \multirow[b]{2}{*}{ Host crop } & \multicolumn{10}{|c|}{ Location and number of collected isolates ${ }^{\mathbf{z}}$} \\
\hline & CA & IL & IN & MI & NY & TX & WA & WI & Italy & Tota \\
\hline Cucurbita maxima & 3 & 4 & 1 & 3 & 0 & 0 & 0 & 0 & 0 & 11 \\
\hline Cucurbita pepo & 10 & 38 & 2 & 4 & 3 & 4 & 5 & 2 & 1 & 69 \\
\hline Cucumis melo & 0 & 4 & 0 & 0 & 0 & 0 & 0 & 0 & 2 & 6 \\
\hline Cucumis sativus & 0 & 6 & 0 & 0 & 0 & 4 & 0 & 0 & 1 & 11 \\
\hline $\begin{array}{l}\text { Cucurbita } \\
\text { moschata }\end{array}$ & 0 & 6 & 0 & 2 & 0 & 0 & 0 & 0 & 0 & 8 \\
\hline $\begin{array}{r}\text { Lagenaria } \\
\text { siceraria }\end{array}$ & 0 & 0 & 0 & 0 & 0 & 0 & 1 & 0 & 0 & 1 \\
\hline Unknown cucurbit & 3 & 0 & 0 & 0 & 0 & 0 & 0 & 0 & 0 & 3 \\
\hline Total & 16 & 58 & 3 & 9 & 3 & 8 & 6 & 2 & 4 & 109 \\
\hline
\end{tabular}

${ }^{\mathrm{z}} \mathrm{CA}=$ California, IL = Illinois, IN = Indiana, MI = Michigan, $\mathrm{NY}=\mathrm{New}$

York, $\mathrm{TX}=$ Texas, $\mathrm{WA}=$ Washington, and $\mathrm{WI}=$ Wisconsin .
Molecular identification of isolates. All 109 collected isolates were used for molecular identification of pathogen species. Mycelia and conidia $(5 \mathrm{mg}$ ) of each isolate were scraped from inoculated cotyledon leaves and DNA was extracted using the E.Z.N.A MicroElute Genomic DNA Kit (Omega Bio-tek Inc., Norcross, GA). PCR was performed to amplify the ITS region using fungal-specific primers ITS1F (5'-CTT GGT CAT TTA GAG GAA GTA A-3') and ITS4 (5'-GCA TAT CAA TAA GCG GAG GA-3') (Gardes and Bruns 1993; White et al. 1990). Amplification was performed in 25- $\mu 1$ reactions using Illustra PuReTaq Ready-To-Go PCR beads (GE Healthcare, Chicago, IL) containing $3 \mu \mathrm{l}$ of DNA, $15 \mu \mathrm{l}$ of nuclease-free distilled water, $2.5 \mu \mathrm{l}$ of $50 \%$ dimethylsulfoxide, $2.5 \mu \mathrm{l}$ of bovine serum albumin, $1 \mu \mathrm{l}$ of $10 \mu \mathrm{M}$ forward primer ITS1F, and $1 \mu \mathrm{l}$ of $10 \mu \mathrm{M}$ reverse primer ITS4. PCR was performed under the following conditions: $95^{\circ} \mathrm{C}$ for $5 \mathrm{~min}$, followed by 40 cycles of $95^{\circ} \mathrm{C}$ for $30 \mathrm{~s}, 43^{\circ} \mathrm{C}$ for $15 \mathrm{~s}$, and $72^{\circ} \mathrm{C}$ for $1 \mathrm{~min}$, with a final extension at $72^{\circ} \mathrm{C}$ for $10 \mathrm{~min}$. The PCR products were cleaned up using the Promega Wizard SV Gel and PCR Clean- Up System (Promega, Madison, WI) and sequenced in both directions using the same ITS1F/ITS4 primers on an ABI Applied Biosystems 3730XL high-throughput DNA capillary sequencer at the University of Illinois W. M. Keck Center for Comparative and Functional Genomics. Sequence contigs were assembled and aligned in Sequencher 5.1 (Gene Code Corporation, Ann Arbor, MI). Sequences were identified based on the NCBI BLAST results (https:// www.ncbi.nlm.nih.gov/BLAST).

Determining genetic variation among isolates using genotypingby-sequencing. Mycelia and conidia of each isolate were scraped from 2-week-old cultures on cotyledons of cucumber Bush Crop and DNA was extracted using the Omega Bio-tek E.Z.N.A MicroElute Genomic DNA Kit. The DNA concentration (in nanograms per microliter) of 109 isolates was determined using a NanoDrop spectrophotometer (Thermo Fisher Scientific, Waltham, MA) and uniformly diluted to the concentration of $25 \mathrm{ng} / \mu \mathrm{l}$ for all of the isolates in 96-well plates. A genotypingby-sequencing (GBS) Illumina library was prepared following the steps of digestion, ligation, and amplification before it was sent for Illumina genomic sequencing (Elshire et al. 2011).

To reduce the complexity of the fungal genomes using restriction enzymes (REs), the HindIII-HF and HinPI combination was shown to give the best and most consistent size between 250 and $350 \mathrm{bp}$ after comparing two enzyme combinations (HindIII-HF+HinPI and HindIII+BfaI). The extracted genomic DNA of all of the isolates was digested using a combination of RE HindIII-HF and HinPI. The restriction reaction mix was prepared in $20-\mu l$ volumes per isolate and contained $2.0 \mu \mathrm{l}$ of $10 \times$ CutSmart Buffer, $0.1 \mu \mathrm{l}$ of rare cutter (HindIII-HF), $0.2 \mu l$ of common cutter (HinPI), $10.2 \mu l$ of molecular biology-grade water, and $7.5 \mu \mathrm{l}$ of uniformly diluted genomic DNA in 96-well plates for the digestion of the PCR product at $37^{\circ} \mathrm{C}$ for $2 \mathrm{~h}$ followed by $80^{\circ} \mathrm{C}$ for $20 \mathrm{~min}$. The resulting product was preserved at $10^{\circ} \mathrm{C}$ until analysis.

The ligation step was prepared in $30-\mu l$ volumes per isolate reaction and contained $2.0 \mu \mathrm{l}$ of $10 \times$ CutSmart Buffer, $3 \mu \mathrm{l}$ of $10 \mathrm{mM}$ dATP in a final concentration of $1 \mathrm{mM}, 0.1 \mu \mathrm{l}$ of concentrated T4 DNA ligase, $0.5 \mu \mathrm{l}$ of $10 \mu \mathrm{M}$ Adapter2, $4.4 \mu \mathrm{l}$ of molecular biology-grade water, and $20 \mu \mathrm{l}$ of digestion PCR product that were mixed in each of the wells in a 96-well plate. The ligation PCR was carried out at $25^{\circ} \mathrm{C}$ for $2 \mathrm{~h}$ followed by $65^{\circ} \mathrm{C}$ for $20 \mathrm{~min}$. The resulting product was preserved at $10^{\circ} \mathrm{C}$ until analysis.

Ligated PCR products of 109 isolates were pooled and cleaned up using AMPure XP bead solution. The cleaned restriction/ligation product was amplified in a total volume of a $50-\mu l$ reaction containing $3 \mu \mathrm{l}$ of template product, $2 \mu \mathrm{l}$ of $10 \mu \mathrm{M}$ Illumina forward and reverse primer mix, $25 \mu \mathrm{l}$ of $2 \times$ Phusion Master Mix, and $20 \mu \mathrm{l}$ of water in a PCR test at $98^{\circ} \mathrm{C}$ for $30 \mathrm{~s}$ and 15 cycles of $98^{\circ} \mathrm{C}$ for $10 \mathrm{~s}$, $68^{\circ} \mathrm{C}$ for $30 \mathrm{~s}$, and $72^{\circ} \mathrm{C}$ for $30 \mathrm{~s}$, followed by $72^{\circ} \mathrm{C}$ for $5 \mathrm{~min}$. The resulting product was preserved at $4^{\circ} \mathrm{C}$ until analysis. The amplified PCR product was cleaned up using the same above-mentioned AMPure XP bead solution, determined for average size and concentration using an Agilent DNA7500 chip Bioanalyzer (Agilent Technologies Inc., Santa Clara, CA), and diluted to $10 \mathrm{nmol}$ in LIB buffer (10 mM of Tris-HCL [EB] with $0.05 \%$ Tween-20). The final product 
was submitted to the University of Illinois W. M. Keck Center for single-end 100-bp Illumina sequencing on a HiSeq 4000 100-nt lane.

DNA sequences were aligned and single nucleotide polymorphism (SNPs) were identified using the TASSEL3.0 Universal Network Enabled Analysis Kit (UNEAK) pipeline (Elshire et al. 2011). The minimum minor allele frequency was set at 0.05 , the maximum minor allele frequency at 0.5 , the minimum call rate at 0 , and the maximum call rate at 1 . SNPs were found in $<89$ of the 109 isolates and those isolates with $<50 \%$ of sites present were removed in TASSEL (TASSEL5; Buckler Laboratory at Cornell University). The final filtered data were exported in a HapMap format and analyzed using R Studio software ( $\mathrm{R}$ version 3.3.2).

Genetic variation. To classify isolates based on SNP similarity, a dendrogram of the isolates from different locations and different hosts was created using a hierarchical clustering method with the Euclidean distance method on the data matrix of 109 isolates $\times 2,266$ SNPs. Each isolate in the tree was labeled based on its geographic location and host using different colors for location and host (Fig. 1). In addition, a $k$-means clustering analysis was applied. $k$-means seeks a good clustering for which the within-cluster variation is as small as possible. Therefore, an elbow method was plotted to calculate the within-cluster sum of squares by different $k$ clusters (Fig. 2). The tree was cut into $k$ groups by choosing different values for $k$ from $k=3$ to 7. This analysis was carried out using the "Hclust" function of R version 3.3.2 (31 October 2016). In addition, pairwise fixation index (Fst) values for populations from different hosts and collection locations were measured, respectively, to quantify the population differentiation using the SNP data (Tables 2 and 3). This analysis was carried out using the Hierfstat package in the same version of $\mathrm{R}$. Meanwhile, the genetic diversity within populations from the same locations was evaluated by the Simpson's index (Simpson 1949) using the Poppr function in the same version of R.

Virulence among the isolates. Because of the difficulty of isolate maintenance of these obligate parasites, only 36 of the 109 isolates survived and were available for virulence testing. Thirty-six isolates (two each from California, Indiana, Michigan, and Texas and 28 from Illinois) were included in this study. Illinois isolates were collected from Cucumis melo, Cucumis sativus, Cucurbita moschata, and Cucurbita pepo in various locations in the state in 2014, 2015,

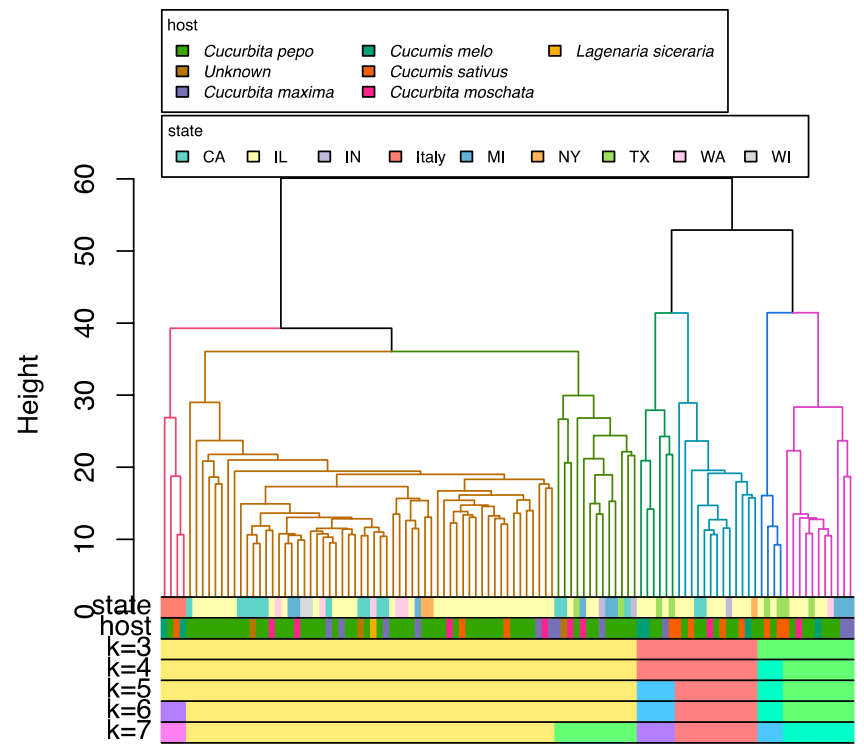

Fig. 1. Seven distinct groups (from left to right: red, brown, light green, green, light blue, blue, and pink) of 109 Podosphaera xanthii isolates with 2,266 single nucleotide polymorphisms, identified by hierarchical clustering on the distance matrix. Different groupings are shown for different values of $k(k=3$ to 7$)$. P. xanthii isolates were collected from six known hosts (Cucumis melo, Cucumis sativus, Cucurbita maxima, Cucurbita moschata, Cucurbita pepo, and Lagenaria siceraria) and one unknown cucurbit host in California (CA), Illinois (IL), Indiana (IN), Michigan (MI), New York (NY), Texas (TX), Washington (WA), Wisconsin (WI), and Italy with $16,58,3,9,3,8,6,2$, and 4 isolates, respectively. and 2016. The isolates from the other four states were collected from Cucurbita maxima and Cucurbita pepo in 2016.

A cotyledon bioassay was conducted to assess the virulence of the isolates. Isolates were obtained in pure culture as previously described. For each isolate, six cotyledon leaves were inoculated. The experiment was repeated five times. The plates were incubated in a growth chamber at $25^{\circ} \mathrm{C}$ with $16 \mathrm{~h}$ of light for 12 to 14 days. The lesion size (in square centimeters) of $P$. xanthii on cotyledons was recorded using ImageJ software (version 1.49; U.S. National Institutes of Health, Bethesda, MD) (Schneider et al. 2012).

The lesion size of 36 isolates was analyzed using analysis of variance. If the lesion sizes were significantly different, the means were separated and compared using Fisher's least significant difference (LSD) at $P=0.05$. To investigate the relationship between lesion size and host crops, locations, and collection years, a linear model was constructed using the value of lesion size as the dependent variable and host, year, latitude, longitude, and the latitude-longitude interaction of collection location of isolates as the independent variables. Host and year were set as categorical variables, whereas latitude and longitude were set as continuous variables. If the model was significant, the means were also separated and compared using Fisher's LSD at $P=0.05$. All statistical analyses for this study were carried out using R Studio.

\section{Results}

Species of the powdery mildew pathogen. Based on the conidia morphological characteristics and the isolate ITS sequences, all examined isolates from the United States and Italy were identified as $P$. xanthii. The average conidia length and width from 32 isolates ranged from 12.79 to $34.71 \times 8.42$ to $21.56 \mu \mathrm{m}$, respectively. Fibrosin bodies were found in all 32 isolates examined and there was an angular shape to the connection points of conidia in chains. These morphological characteristics met the description of $P$. xanthii reported by Braun and Cook (2012). No chasmothecia were found on any of the collected leaf samples. The PCR tests with all 109 isolates produced DNA sequences of $601 \mathrm{bp}$, which had 100\% identity and overlap with GenBank accession JQ728480, a P. xanthii found on Senna occidentalis in Mexico.

SNP detection. After SNPs without a reference genome were detected using the UNEAK pipeline (Lu et al. 2012, 2013), isolates with $<50 \%$ of these sites present were removed; loci missing in more than half of the isolates were removed using TASSEL 3.0. In the end, we

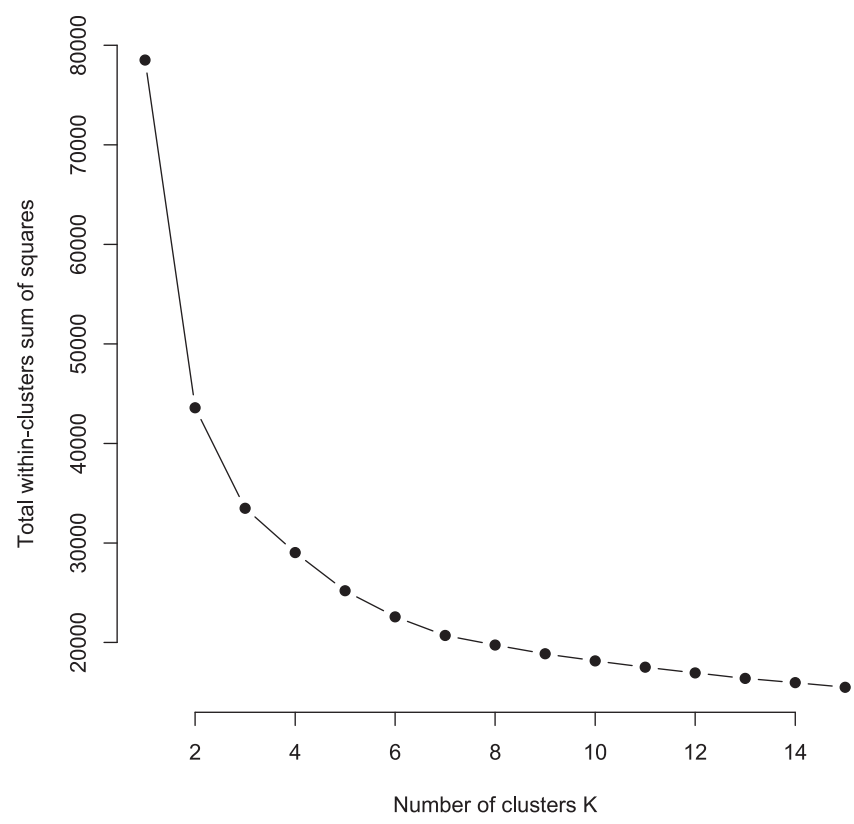

Fig. 2. Elbow analysis to visualize within-clusters sum of squares at different $k$ values. Based on our analysis, the "elbow" shows up when $k=3$, and the within-cluster variations decrease as $k$ increases. 
obtained a HapMap genotype with single letters (hmp) in 109 isolates with 2,266 SNPs from different locations and hosts.

Hierarchical clustering of the isolates. We found that isolates collected in Illinois had high within-sample genetic diversity, which was shown by both clustering analysis (Fig. 1) and Simpson's index values (Simpson 1949), but there was higher genetic similarity between Illinois and other locations based on Fst calculations (Table 2). A hierarchical clustering analysis on the distance matrix of 109 isolates $\times 2,266$ SNPs identified three to seven clades (Fig. 1). The height of the tree was defined by Euclidean distances among 109 isolates based on their SNPs. When $k=3,51$ isolates collected in Illinois showed high genetic diversity because they were distributed in all three groups. Genetic diversity within the samples from the same location was calculated with Simpson's index (Simpson 1949), which is simply 1 minus the sum of squared genotype frequencies. Simpson's index yields 0 when genotypes are not different and 1 when genotypes are different. When within-population genetic diversity was evaluated, genetic diversity from Illinois (Simpson's index of 0.9828) was higher than that of California (Simpson's index of 0.9375) (Table 2). The pairwise genetic difference calculated by Fst supported this conclusion by showing that isolates collected in Illinois shared genetic similarity with isolates from any of the other locations, as indicated with lower Fst values; isolates between other locations had relatively higher pairwise Fst values, indicating that isolates from different locations other than Illinois had higher genetic variations (Table 2).

Theoretically, the value of $k$ should be chosen at some point (the "elbow") such that the within-cluster variation decreases significantly. However, this elbow cannot always be unambiguously decided. Based on our analysis, the elbow appeared when $k=3$ but the within-cluster variations continued to decrease as $k$ increased (Fig. 2). Therefore, the hierarchical tree was cut into $k$ groups based on different $k$ values ranging from 3 (the highest height) to 7 (the lowest height). The isolates from some locations showed higher diversity than other locations. Eight isolates collected from Texas samples showed high genetic diversity because they were distributed in all three groups. When $k=4$, two isolates from Illinois and two isolates from Texas were separated as an additional group. When $k=5$, an additional four isolates from Illinois and two isolates from Texas were separated as an additional group. When $k=6$, four isolates from Italy were separated from the U.S. isolates as a separate group. When $k=7$, three isolates from California, three from Illinois, two from Indiana, three from Michigan, and two isolates from Texas were separated as a new group. Although these isolates had high genetic variation, we did not find any trends in host or collection location based on the clustering analysis. Relatively low levels of genetic variation were found among $P$. xanthii populations from different hosts of collections based on the pairwise Fst test (Table 3), except moderately higher Fst values were found between Cucurbita maxima and Cucumis melo (0.1004) and Cucurbita maxima and Cucumis sativus (0.1137).

Virulence among the isolates. There was no significant difference in variance between the virulence experiments; therefore, lesion size values of the experiments were combined for analysis. There were significant differences $(P<0.0001)$ among the lesion size values of the 36 isolates tested (Table 4). Similarly, there were significant differences among lesion size values of 28 isolates from Illinois. Because the model was significant, the means of each level of year and host were compared and separated by Fisher's LSD method at $P=0.05$. Mean separation showed that isolate ILV1_1_ 16 from Illinois had the highest lesion size value $\left(1.03 \mathrm{~cm}^{2}\right)$ and isolate ILV4_2_16 had the lowest lesion size value $\left(0.59 \mathrm{~cm}^{2}\right)$ (Table 5).

Table 4. Analysis of variance for lesion size values $\left(\right.$ in $\left.\mathrm{cm}^{2}\right)$ after inoculation of cucumber cotyledons with 36 Podosphaera xanthii isolates

\begin{tabular}{lccccc}
\hline Term & $\begin{array}{c}\text { Degrees of } \\
\text { freedom }\end{array}$ & Sum of squares & Mean square & $\boldsymbol{F}$ value & $\boldsymbol{P}$ value \\
\hline Isolate & 35 & 18.02 & 0.51 & 6.28 & $<0.0001$ \\
Residual & 1,316 & 107.82 & 0.08 & & \\
\hline
\end{tabular}

Table 2. Pairwise genetic difference of 109 Podosphaera xanthii isolates between different locations of collections calculated by the fixation index

\begin{tabular}{|c|c|c|c|c|c|c|c|c|c|c|}
\hline \multirow[b]{2}{*}{ Location $^{x}$} & \multicolumn{9}{|c|}{ Location $^{y}$} & \multirow[b]{2}{*}{ Simpson's index } \\
\hline & CA (16) & IL (58) & IN (3) & MI (9) & NY (3) & TX (8) & WA (6) & WI (2) & Italy (4) & \\
\hline CA & 0.0000 & 0.0260 & 0.1047 & 0.1234 & 0.0686 & 0.1886 & 0.0359 & 0.0404 & 0.1355 & 0.9375 \\
\hline IL & 0.0260 & 0.0000 & 0.0247 & 0.0476 & 0.0104 & 0.0562 & 0.0179 & 0.0153 & 0.0330 & 0.9828 \\
\hline IN & 0.1047 & 0.0247 & 0.0000 & 0.0782 & 0.2480 & 0.0868 & 0.2308 & 0.3533 & 0.3357 & 0.6667 \\
\hline MI & 0.1234 & 0.0476 & 0.0782 & 0.0000 & 0.1886 & 0.1227 & 0.1568 & 0.1469 & 0.2585 & 0.8889 \\
\hline NY & 0.0686 & 0.0104 & 0.2480 & 0.1886 & 0.0000 & 0.1915 & 0.1462 & 0.2903 & 0.2434 & 0.6667 \\
\hline $\mathrm{TX}$ & 0.1886 & 0.0562 & 0.0868 & 0.1227 & 0.1915 & 0.0000 & 0.2265 & 0.2142 & 0.2796 & 0.8750 \\
\hline WA & 0.0359 & 0.0179 & 0.2308 & 0.1568 & 0.1462 & 0.2265 & 0.0000 & 0.1073 & 0.2360 & 0.8333 \\
\hline WI & 0.0404 & 0.0153 & 0.3533 & 0.1469 & 0.2903 & 0.2142 & 0.1073 & 0.0000 & 0.3643 & 0.5000 \\
\hline Italy & 0.1355 & 0.0330 & 0.3357 & 0.0000 & 0.2585 & 0.2434 & 0.2796 & 0.2360 & 0.0000 & 0.7500 \\
\hline Total & - & - & - & - & - & - & - & - & - & 0.9908 \\
\hline
\end{tabular}

${ }^{\mathrm{x}} \mathrm{CA}=$ California, $\mathrm{IL}=$ Illinois, $\mathrm{IN}=$ Indiana, $\mathrm{MI}=$ Michigan, $\mathrm{NY}=$ New York, $\mathrm{TX}=$ Texas, $\mathrm{WA}=$ Washington, and WI = Wisconsin.

y The number of isolates from each location are given in parentheses.

z Simpson's index number for genetic diversity within each location.

Table 3. Pairwise genetic difference of 109 Podosphaera xanthii isolates among different host of collections calculated by fixation index

\begin{tabular}{|c|c|c|c|c|c|c|c|}
\hline Host & $\begin{array}{l}\text { Cucurbita } \\
\text { pepo }(69)^{\mathrm{z}}\end{array}$ & $\begin{array}{c}\text { Cucurbita } \\
\text { maxima (11) }\end{array}$ & $\begin{array}{l}\text { Cucumis } \\
\text { melo }(6)\end{array}$ & $\begin{array}{c}\text { Cucumis } \\
\text { sativus (11) }\end{array}$ & $\begin{array}{c}\text { Cucurbita } \\
\text { moschata }(8)\end{array}$ & $\begin{array}{c}\text { Lagenaria } \\
\text { siceraria (1) }\end{array}$ & Unknown (3) \\
\hline Cuсurbita реро & 0.0000 & & & & & & \\
\hline Cucurbita maxima & 0.0153 & 0.0000 & & & & & \\
\hline Cucumis melo & 0.0246 & $0.1004 *$ & 0.0000 & & & & \\
\hline Cucumis sativus & 0.0347 & $0.1137 *$ & 0.0454 & 0.0000 & & & \\
\hline Cucurbita moschata & 0.0068 & 0.0433 & 0.0741 & 0.0683 & 0.0000 & & \\
\hline Lagenaria siceraria & 0.0066 & 0.0498 & 0.1254 & 0.0745 & 0.0627 & 0.0000 & \\
\hline Unknown & 0.0119 & 0.0609 & 0.1519 & 0.1185 & 0.0750 & 0.1884 & 0.0000 \\
\hline
\end{tabular}

$\mathrm{z}$ The numbers of isolates from each host are indicated in parentheses beside each host. Values with an asterisk indicate relatively high genetic diversity between the two hosts. 
For the 28 Illinois isolates, we found that the year, host, latitude, longitude, and latitude-longitude interactions had significant effects on lesion size values $(P<0.0001)$ (Table 6). Because the effect was significant, the means of each level of year and host were compared and separated by Fisher's LSD test at $P=0.05$. Mean separation showed that the isolates collected in 2014 (lesion size $=0.87 \mathrm{~cm}^{2}$ ) were more virulent than those collected in 2015 (lesion size = $0.75 \mathrm{~cm}^{2}$ ) and 2016 (lesion size $=0.76 \mathrm{~cm}^{2} ; P<0.0001$ ) (Table 7). Mean separation also showed that the isolates collected from Cucumis sativus were more virulent (lesion size $=0.87 \mathrm{~cm}^{2}$ ) than isolates collected from Cucurbita pepo (lesion size $=$ $0.73 \mathrm{~cm}^{2} ; P<0.0001$ ) (Table 7). According to the summary of the linear model, the estimated coefficient of latitude was $9.29 \pm 1.83$ and the estimated coefficient of the absolute value of longitude was $4.13 \pm 0.82$; this indicates that as the latitude and the absolute value of longitude increased, the virulence of the isolates increased.

\section{Discussion}

This study identified $P$. xanthii as the only causative agent of powdery mildew of cucurbits in the Midwest and other states in the Eastern, Southern, and Western United States included in this study. The genetic diversity of isolates varied from different regions. To our knowledge, this is the first report of the identification of the species causing powdery mildew of cucurbits in the Midwest. The conclusions from this study are expected to help develop effective strategies for management of the disease in Illinois, the Midwest region, and likely throughout the United States. For example, cucurbit breeders should develop resistant cultivars targeting existing $P$. xanthii isolates in these regions.

The ITS region of rDNA has been widely used for the identification of powdery mildew fungi (Braun and Cook 2012) and numerous

Table 6. Analysis of variance for lesion size values $\left(\mathrm{in} \mathrm{cm}^{2}\right)$ in relation to the year of collection, host, and host locations after inoculation of cucumber cotyledons with 28 Podosphaera xanthii isolates from Illinois

\begin{tabular}{lcccrr}
\hline Term & $\begin{array}{c}\text { Degrees of } \\
\text { freedom }\end{array}$ & $\begin{array}{c}\text { Sum of } \\
\text { squares }\end{array}$ & $\begin{array}{c}\text { Mean } \\
\text { square }\end{array}$ & $\begin{array}{c}\boldsymbol{F} \\
\text { value }\end{array}$ & $\boldsymbol{P}$ value \\
\hline Year $^{\mathrm{w}}$ & 2 & 1.10 & 0.55 & 6.51 & 0.0016 \\
Host $^{\mathrm{x}}$ & 3 & 1.68 & 0.84 & 9.95 & $<0.0001$ \\
Latitude $^{\mathrm{y}}$ & 1 & 1.03 & 1.03 & 12.15 & 0.0005 \\
Longitude $^{\mathrm{y}, \mathrm{z}}$ & 1 & 1.16 & 1.16 & 13.71 & 0.0002 \\
Latitude-longitude $^{\mathrm{z}}$ & 1 & 2.19 & 2.19 & 25.89 & $<0.0001$ \\
Residuals & 960 & 81.23 & 0.08 & & \\
\hline
\end{tabular}

w Isolates were collected in 2014, 2015, and 2016.

${ }^{x}$ Isolates were collected from Cucumis melo, Cucumis sativus, Cucurbita moschata, and Cucurbita pepo.

y Latitude and longitude information was collected from the Get Latitude and Longitude website (https://www.latlong.net/).

$\mathrm{z}$ The absolute value of longitude was used in this study.

Table 5. Lesion size on cotyledon leaves after inoculation of cucumber cotyledons with Podosphaera xanthii isolates

\begin{tabular}{|c|c|c|c|c|c|c|c|}
\hline \multirow[b]{2}{*}{ Isolate } & \multirow[b]{2}{*}{ Year collected } & \multirow[b]{2}{*}{ Source host } & \multicolumn{4}{|c|}{ Location of source host } & \multirow[b]{2}{*}{ Lesion size $\left(\mathrm{cm}^{2}\right)^{\mathrm{z}}$} \\
\hline & & & State $^{\mathrm{x}}$ & Town & Latitude $^{y}$ & Longitude & \\
\hline 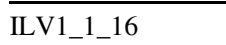 & 2016 & Cucurbita moschata & $\mathrm{IL}$ & Vandalia & 38.96 & -89.09 & $1.03 \mathrm{a}$ \\
\hline TX3_2 & 2016 & Cucumis sativus & $\mathrm{TX}$ & Amarillo & 35.22 & -101.83 & $0.98 \mathrm{ab}$ \\
\hline ILN3_2_16 & 2016 & Cucurbita pepo & $\mathrm{IL}$ & Hancock & 39.82 & -85.85 & $0.98 \mathrm{ab}$ \\
\hline IL17_JPGH & 2014 & Cucumis sativus & $\mathrm{IL}$ & Champaign & 40.12 & -88.24 & $0.97 \mathrm{a}-\mathrm{c}$ \\
\hline IL06_QGH & 2014 & Cucumis sativus & IL & Champaign & 40.12 & -88.24 & $0.90 \mathrm{a}-\mathrm{d}$ \\
\hline TX1_2 & 2016 & Cucurbita pepo & $\mathrm{TX}$ & Amarillo & 35.22 & -101.83 & $0.88 \mathrm{~b}-\mathrm{d}$ \\
\hline IN3_1 & 2016 & Cucurbita pepo & IN & Hancock & 39.82 & -85.85 & $0.86 \mathrm{c}-\mathrm{e}$ \\
\hline IL14_JP081603_3 & 2015 & Cucurbita pepo & IL & Calhoun & 39.17 & -90.66 & $0.86 \mathrm{c}-\mathrm{f}$ \\
\hline IL22 & 2015 & Cucurbita moschata & $\mathrm{IL}$ & Champaign & 40.12 & -88.24 & $0.84 \mathrm{c}-\mathrm{g}$ \\
\hline ILD1_16 & 2016 & Cucumis melo & $\mathrm{IL}$ & Decatur & 39.84 & -88.95 & $0.84 \mathrm{c}-\mathrm{g}$ \\
\hline MI3_1 & 2016 & Cucurbita pepo & MI & Benton Harbor & 42.12 & -86.45 & $0.84 \mathrm{c}-\mathrm{g}$ \\
\hline IL04_CL0829_3 & 2015 & Cucumis melo & $\mathrm{IL}$ & Champaign & 40.12 & -88.24 & $0.84 \mathrm{c}-\mathrm{g}$ \\
\hline IL10_JP0816_4 & 2015 & Cucurbita pepo & $\mathrm{IL}$ & Calhoun & 39.17 & -90.66 & $0.83 \mathrm{c}-\mathrm{g}$ \\
\hline IL18_NP0906_2 & 2015 & Cucurbita pepo & IL & Champaign & 40.12 & -88.24 & $0.80 \mathrm{~d}-\mathrm{h}$ \\
\hline IL11_JP081601_2 & 2015 & Cucurbita pepo & IL & Calhoun & 39.17 & -90.66 & $0.79 \mathrm{~d}-\mathrm{h}$ \\
\hline IL09_JP0809_3 & 2015 & Cucurbita pepo & $\mathrm{IL}$ & Huntley & 42.17 & -88.43 & $0.76 \mathrm{~d}-\mathrm{h}$ \\
\hline CA8-1 & 2016 & Unknown & $\mathrm{CA}$ & Salinas & 36.68 & -121.66 & $0.75 \mathrm{~d}-\mathrm{h}$ \\
\hline IL05_Q5 & 2014 & Cucumis sativus & $\mathrm{IL}$ & Champaign & 40.12 & -88.24 & $0.75 \mathrm{~d}-\mathrm{h}$ \\
\hline ILN2 & 2016 & Cucurbita pepo & IL & Naperville & 41.75 & -88.15 & $0.75 \mathrm{e}-\mathrm{h}$ \\
\hline IN3_2 & 2016 & Cucurbita pepo & IN & Fortville & 39.93 & -85.85 & $0.74 \mathrm{f}-\mathrm{h}$ \\
\hline IL20_PP082401_2 & 2015 & Cucurbita moschata & IL & Pekin & 40.57 & -89.64 & $0.73 \mathrm{f}-\mathrm{i}$ \\
\hline IL08_JP0809_2 & 2015 & Cucurbita pepo & $\mathrm{IL}$ & Huntley & 42.17 & -88.43 & $0.73 \mathrm{f}-\mathrm{i}$ \\
\hline IL19_NP0906_3 & 2015 & Cucurbita pepo & $\mathrm{IL}$ & Champaign & 40.12 & -88.24 & $0.72 \mathrm{f}-\mathrm{i}$ \\
\hline MI6_1 & 2016 & Cucurbita pepo & MI & Benton Harbor & 42.12 & -86.45 & $0.72 \mathrm{~g}-\mathrm{i}$ \\
\hline IL23 & 2015 & Cucurbita moschata & $\mathrm{IL}$ & Champaign & 40.12 & -88.24 & $0.72 \mathrm{~g}-\mathrm{i}$ \\
\hline IL21_PP082404_1 & 2015 & Cucurbita moschata & $\mathrm{IL}$ & Green Valley & 40.41 & -89.64 & $0.71 \mathrm{~g}-\mathrm{j}$ \\
\hline ILD2_16 & 2016 & Cucumis melo & $\mathrm{IL}$ & Decatur & 39.84 & -88.95 & $0.70 \mathrm{~h}-\mathrm{j}$ \\
\hline IL30_YS0829_1 & 2015 & Cucurbita pepo & $\mathrm{IL}$ & Champaign & 40.12 & -88.24 & $0.69 \mathrm{~h}-\mathrm{j}$ \\
\hline IL28_YS0816_3 & 2015 & Cucurbita pepo & $\mathrm{IL}$ & Douglas & 39.76 & -88.21 & $0.69 \mathrm{~h}-\mathrm{j}$ \\
\hline IL24_P08230202 & 2015 & Cucurbita pepo & $\mathrm{IL}$ & Hampshire & 42.10 & -88.53 & $0.68 \mathrm{~h}-\mathrm{j}$ \\
\hline CA9-1 & 2016 & Cucurbita maxima & $\mathrm{CA}$ & Hollister & 36.85 & -121.40 & $0.68 \mathrm{~h}-\mathrm{j}$ \\
\hline IL29_YS082303_1 & 2015 & Cucurbita pepo & $\mathrm{IL}$ & Huntley & 42.17 & -88.43 & $0.68 \mathrm{~h}-\mathrm{j}$ \\
\hline IL33_YS0725_2 & 2015 & Cucurbita pepo & $\mathrm{IL}$ & Arcola & 39.68 & -88.31 & $0.67 \mathrm{~h}-\mathrm{j}$ \\
\hline IL5_16 & 2016 & Cucurbita pepo & $\mathrm{IL}$ & Wayne & 41.95 & -88.24 & $0.60 \mathrm{ij}$ \\
\hline IL7_16 & 2016 & Cucurbita pepo & $\mathrm{IL}$ & Pekin & 40.57 & -89.64 & $0.59 \mathrm{j}$ \\
\hline ILV4_2_16 & 2016 & Cucurbita pepo & $\mathrm{IL}$ & Vandalia & 38.96 & -89.09 & $0.59 \mathrm{j}$ \\
\hline
\end{tabular}

${ }^{\mathrm{x}} \mathrm{IL}=$ Illinois, $\mathrm{TX}=$ Texas, $\mathrm{IN}=$ Indiana, $\mathrm{MI}=$ Michigan, and CA = California.

y Latitude and longitude are given in degrees.

${ }^{\mathrm{z}}$ Each value represents the average of eight cotyledons. Values followed by the same letter are not significantly different from each other according to the Fisher's significant difference test at $P=0.05$. 
ITS sequences of powdery mildew fungi are available in GenBank. Using morphological characteristics of fungal conidia and molecular analysis of the ITS in our studies, all isolates were identified as $P$. xanthii. G. cichoracearum, another species reported as an incitant of cucurbit powdery mildew in Europe (Kř́stková et al. 2009), was not identified in this study.

This study began with the investigation of powdery mildew of cucurbits in Illinois, so the majority of the isolates were collected in Illinois. Higher genetic diversity of isolates collected in Illinois was proven by both clustering analysis (Fig. 1) and Fst calculation (Table 2). We also point out that this conclusion might be confounded by the fact that the number of isolates collected in Illinois (58 of 109 isolates) was dominant.

In our study, four isolates from Italy showed relatively low genetic diversity among themselves; they were grouped together with some isolates from the United States when $k=3,4$, and 5. When $k$ was increased to six groups, these isolates were separated from the U.S. isolates in that they grouped together. Thus, the results indicated relatively high genetic diversity between isolates from Italy and isolates from the United States. This conclusion was supported by higher Fst values between Italy and the United States (Table 2).

Our results do not contradict or support the conclusions made by Pirondi et al. (2015) who reported low genetic diversity between isolates of $P$. xanthii from Europe and the United States, since different methods for analyzing sequences were used. We used a GBS method (Elshire et al. 2011), which reveals more polymorphisms than the traditional techniques, such as multilocus sequence typing (MLST) and amplified fragment length polymorphism (AFLP), used by Pirondi et al. (2015). The MLST technique amplifies housekeeping genes that usually tend to be conservative. AFLP can only detect differences in the sequence length; it cannot detect nucleotide polymorphisms with the same-length base pairs. We believe that both clustering methods used in our study accurately identified genetic diversity among isolates of the powdery mildew pathogen.

In the meantime, we suggest that more investigations are needed to analyze the genetic diversity of the powdery mildew pathogen of cucurbits in different regions, as this information will help to better understand the development of pathogen resistance to fungicides and further enhance effective management of the disease. However, we do not have information on the fields of origin for some of the 109 isolates, which makes it incomplete and not high enough resolution for investigation of genetic analysis of isolates by distance within fields. Future studies can reveal whether there is more variation within a field than across fields, or the opposite, as spores of the pathogen are airborne and can be carried long distances.

Significant virulence among $P$. xanthii isolates was expected, as significant genetic variation existed among the isolates tested. The higher virulence of isolates from earlier years (2014) suggests that keeping subculturing isolates in vivo over years can possibly increase their virulence. Because Cucumis sativus was used as the host plant for this in vivo study and virulence analysis, higher virulence of isolates originally collected from Cucumis sativus suggests better adaptation of fungi on the same hosts compared with these isolates

Table 7. Mean lesion size values after inoculation of cucumber cotyledons with Podosphaera xanthii isolates from Illinois

\begin{tabular}{lc}
\hline Variable & Lesion size $\left(\mathbf{c m}^{\mathbf{2}}\right)^{\mathbf{z}}$ \\
\hline Year & \\
2014 & $0.87 \mathrm{a}$ \\
2015 & $0.75 \mathrm{~b}$ \\
2016 & $0.76 \mathrm{~b}$ \\
Host & \\
Cucumis sativus & $0.87 \mathrm{a}$ \\
Cucurbita moschata & $0.84 \mathrm{ab}$ \\
Cucumis melo & $0.79 \mathrm{~b}$ \\
Cucurbita pepo & $0.73 \mathrm{c}$ \\
\hline
\end{tabular}

${ }^{\mathrm{z}}$ Values followed by the same letter are not significantly different from each other according to Fisher's significant difference test at $P=0.05$. collected from hosts other than Cucumis sativus. Because the majority of the isolates tested for virulence were collected from Illinois, additional investigation could reveal further virulence variation among $P$. xanthii isolates from other geographic regions.

$P$. xanthii is an obligate parasite and thus it needs a host for its survival; chasmothecia of $P$. xanthii have not been observed in Illinois but were discovered in other parts of the United States and in Europe (McGrath 1991; McGrath et al. 1996; Pirondi et al. 2015). A random mating test from the previous research showed deviation from mating type in a 1:1 ratio in the population from the United States, which suggests asexual reproduction with a large amount of conidia production as the predominant type of reproduction of this species (Pirondi et al. 2015). Therefore, questions of how $P$. xanthii reaches cucurbit fields in Illinois and how existing genetic variation is maintained in the pathogen are often asked. For survival of $P$. xanthii in the Midwest region, the pathogen could survive on cucurbits produced indoors (e.g., greenhouses). Another possibility is that $P$. xanthii overwinters on other perennial host plants, where it could produce chasmothecia. Some reported host plants of $P$. xanthii and its synonyms $P$. fusca, $P$. phaseoli, and Sphaerotheca fusca are plants in the families Asteraceae, Fabaceae, Solanaceae, Orobanchaceae, and Verbenaceae. (To note, this information was previously found at http://www.erysiphales.wsu.edu managed by Dr. Dean Glawe, but unfortunately Dr. Glawe is no longer with Washington State University and this database is now offline.) For example, it has been reported that Calendula arvensis is colonized by $P$. xanthii (Fernández-Ortuño et al. 2008).

Conidia of $P$. xanthii are airborne and can be carried long distances by wind (Glawe 2008). It is likely that the conidia from the Northern United States, including the Midwest, are dispersed in the fall to the Southern United States where cucurbits are grown during winter. During summer, $P$. xanthii conidia are blown from the southern to the northern states. This is a common way of moving $P$. xanthii conidia, as we have observed infection of cucurbit plants in open fields 2 to 3 weeks earlier in southern Illinois than in northern Illinois (M. Babadoost, unpublished data)

Development of genetic diversity in $P$. xanthii is not clearly known, especially considering the lack of sexual reproduction. One possibility for increasing genetic variation in this pathogen is the occurrence of parasexuality in its hyphae. Another more likely possible explanation for developing genetic variation is mutation, especially for developing resistance to fungicides. Powdery mildew of cucurbits is mainly managed by the application of fungicides, and the development of pathogen resistance to several fungicides has been reported (Bellón-Gómez et al. 2014; Burdon 1993; Lebeda et al. 2010). Intensive research is needed to investigate the biology of $P$. xanthii on cucurbits, which could provide useful information for management of the pathogen.

\section{Acknowledgment}

The authors thank Daniel Raudabaugh and Tiffany Bone from Dr. Miller's laboratory for their technical support in the molecular identification of fungal species; Dr. Patrick Brown and his laboratory technician, Shilpa Pradeep, for their technical support in GBS; and Dr. Alessandro Pirondi for providing DNA samples from Italy.

\section{Literature Cited}

Al-Sadi, A. M., Al-Raisi, I. J., Al-Azri, M., Al-Hasani, H., Al-Shukaili, M. S., AlShuraiqi, S. M., Al-Fahdi, K. O., and Deadman, M. L. 2012. Population structure and management of Podosphaera pannosa associated with peach powdery mildew in Oman. J. Phytopathol. 160:647-654.

Bellón-Gómez, D., Vela-Corcía, D., Pérez-García, A., and Torés, J. A. 2014 Sensitivity of Podosphaera xanthii populations to anti-powdery-mildew fungicides in Spain. Pest Manag. Sci. 71:1407-1413.

Braun, U., and Cook, R. T. A. 2012. Taxonomic Manual of the Erysiphales (Powdery Mildews), CBS Biodiversity Series No. 11. CBS, Utrecht, Netherlands.

Burdon, J. J. 1993. Genetic variation in pathogen populations and its implications for adaptation to host resistance. Pages 41-56 in: Durability of Disease Resistance. T. Jacobs and J. E. Parlevliet, eds. Kluwer, Dordrecht, Netherlands.

Chen, R.-S., Chu, C., Cheng, C.-W., Chen, W.-Y., and Tsay, J.-G. 2008 Differentiation of two powdery mildews of sunflower (Helianthus annuus) 
by a PCR-mediated method based on ITS sequences. Eur. J. Plant Pathol. 121: $1-8$.

Elshire, R. J., Glaubitz, J. C., Sun, Q., Poland, J. A., Kawamoto, K., Buckler, E. S., and Mitchell, S. E. 2011. Arobust, simple genotyping-by-sequencing (GBS) approach for high diversity species. PLoS One 6:e19379.

Fernández-Ortuño, D., Torés, J. A., de Vicente, A., and Pérez-García, A. 2008. Field resistance to QoI fungicides in Podosphaera fusca is not supported by typical mutations in the mitochondrial cytochrome b gene. Pest Manag. Sci. 64:694-702.

Gardes, M., and Bruns, T. D. 1993. ITS primers with enhanced specificity for basidiomycetes application to the identification of mycorrhizae and rusts. Mol. Ecol. 2:113-118.

Garibaldi, A., Bertetti, D., Amatulli, M. T., and Gullino, M. L. 2011. Powdery mildew caused by Golovinomyces cichoracearum on moth mullein (Verbascum blattaria) in Italy. Plant Dis. 95:225.

Glawe, D. A. 2008. The powdery mildews: A review of the world's most familiar (yet poorly known) plant pathogens. Annu. Rev. Phytopathol. 46:27-51.

Islam, S. Z., Babadoost, M., Lambert, K. N., Ndeme, A., and Fouly, H. M. 2005. Characterization of Phytophthora capsici isolates from processing pumpkin in Illinois. Plant Dis. 89:191-197.

Jossey, S., and Babadoost, M. 2008. Occurrence and distribution of pumpkin and squash viruses in Illinois. Plant Dis. 92:61-68.

Kř́stková, E., Lebeda, A., and Sedláková, B. 2009. Species spectra, distribution and host range of cucurbit powdery mildews in the Czech Republic, and in some other European and Middle Eastern countries. Phytoparasitica 37:337-350.

Lebeda, A. 1983. The genera and species spectrum of cucumber powdery mildew in Czechoslovakia. Artens. Echt. Mehl. Gurkenpf. Tsche. 108:71-79.

Lebeda, A., Kristkova, E., Sedlakova, B., Coffey, M. D., and McCreight, J. 2011. Gaps and perspectives of pathotype and race determination in Golovinomyces cichoracearum and Podosphaera xanthii. Mycoscience 52:159-164.

Lebeda, A., McGrath, M. T., and Sedláková, B. 2010. Fungicide resistance in cucurbit powdery mildew fungi. Pages 221-246 in: Fungicides. O. Carisse, ed. InTech, London, UK.

Lu, F., Glaubitz, J. C., Harriman, J., Casstevens, T., and Elshire, R. J., eds. 2012. TASSEL 3.0-Universal Network Enabled Analysis Kit (UNEAK) pipeline documentation. https://bytebucket.org/tasseladmin/tassel-5-source/wiki/docs/ TasselPipelineUNEAK.pdf

Lu, F., Lipka, A. E., Glaubitz, J., Elshire, R., Cherney, J. H., Casler, M. D., Buckler, E. S., and Costich, D. E. 2013. Switchgrass genomic diversity, ploidy, and evolution: Novel insights from a network-based SNP discovery protocol. PLoS Genet. 9:e1003215.
McGrath, M. T. 1991. Cleistothecia of the powdery mildew fungus Sphaerotheca fuliginea observed on pumpkin in New York. Plant Dis. 75:1075.

McGrath, M. T. 2001. Fungicide resistance in cucurbit powdery mildew: Experiences and challenges. Plant Dis. 85:236-245.

McGrath, M. T. 2017. Powdery mildew. Pages 62-64 in: Compendium of Cucurbit Diseases and Pests. A. P. Keinath, W. M. Wintermantel, and T. A. Zitter, eds. American Phytopathological Society, St. Paul, MN.

McGrath, M. T., Staniszewska, H., Shishkoff, N., and Casella, G. 1996. Distribution of mating types of Sphaerotheca fuliginea in the United States. Plant Dis. 80:1098-1102.

McGrath, M. T., Wyenandt, C. A., and Stevenson, K. L. 2019. Occurrence of fungicide resistance in pathogens of non-solanaceous vegetable crops. Pages 309-332 in: Fungicide Resistance in North America, 2nd ed. K. L. Stevenson, M. T. McGrath, and C. A. Wyenandt, eds. American Phytopathological Society, St. Paul, MN.

Miazzi, M., Laguardia, C., and Faretra, F. 2011. Variation in Podosphaera xanthii on cucurbits in southern Italy. J. Phytopathol. 159:538-545.

Nicot, P. C., Bardin, M., and Dik, A. J. 2002. Basic methods for epidemiological studies of powdery mildews: Culture and preservation of isolates, production and delivery of inoculum, and disease assessment. Pages 83-99 in: The Powdery Mildews: A Comprehensive Treatise. R. R. Belanger, W. R. Bushnell, A. J. Dik, and T. L. W. Carver, eds. American Phytopathological Society, St. Paul, MN.

Pérez-García, A., Romero, D., Fernandez-Ortuno, D., Lopez-Ruiz, F., De Vicente, A., and Tores, J. A. 2009. The powdery mildew fungus Podosphaera fusca (synonym Podosphaera xanthii), a constant threat to cucurbits. Mol. Plant Pathol. 10:153-160.

Pirondi, A., Vela-Corcia, D., Dondini, L., Brunelli, A., Perez-Garcia, A., and Collina, M. 2015. Genetic diversity analysis of the cucurbit powdery mildew fungus Podosphaera xanthii suggests a clonal population structure. Fungal Biol. 119:791-801.

Ravanlou, A., and Babadoost, M. 2015. Development of bacterial spot, incited by Xanthomonas cucurbitae, in pumpkin fields. HortScience 50:714-720.

Schneider, C. A., Rasband, W. S., and Eliceiri, K. W. 2012. NIH Image to ImageJ: 25 years of image analysis. Nat. Methods 9:671-675.

Simpson, E. H. 1949. Measurement of diversity. Nature 163:688.

White, T. J., Bruns, T., Lee, S., and Taylor, J. 1990. Amplification and direct sequencing of fungal ribosomal RNA genes for phylogenetics. Pages 315-322 in: PCR Protocols: A Guide to Methods and Applications. M. A. Innis, D. H. Gelfand, J. J. Sninsky, and T. J. White, eds. Academic Press, New York, NY. 